\title{
ANALISIS PENGUATAN PENDIDIKAN KARAKTER PESERTA DIDIK MELALUI KEGIATAN EKSTRAKURIKULER TAHFIDZ AL QUR'AN PADA SISWA SD MUHAMMADIYAH 1 TRENGGALEK
}

\author{
Rizka Ayu Fitrianingsih ${ }^{\mathbf{1}}$, Nugrananda Janattaka ${ }^{2}$. \\ rizkaayu323@gmail.com ${ }^{1}$, nugrananda@stkippgritulungagung.ac.id ${ }^{2}$ \\ PGSD, STKIP PGRI TULUNGAGUNG ${ }^{1}$ \\ Jalan mayor sujadi no. 7 tulungagung telp./fax 0355-321426. \\ No Handphone:+6285546301639
}

\begin{abstract}
Abstrak: Tujuan penelitian ini untuk mendiskripsikan pelasanaan kegiatan ekstrakurikuler tahfidz al qur'an, untuk mendiskripsikan pembentukan karakter pada peserta didik melalui kegiatan ekstrakurikuler tahfidz al qur'an, untuk mendiskripsikan dampak kegiatan ekstrakurikuler tahfidz al qur'an terhadap penguatan pendidikan karakter siswa. Metode penelitian ini termasuk jenis penelitian kualitatif deskriptif. Teknik pengumpulan data yang digunakan berupa observasi, menggunakan observasi terus terang atau tersamar, observasi ini pengamatan yang dilakukan pada siswa yang mengikuti kegiatan ekstrakurikuler tahfidz al-qur'an yaitu kelas 3 dengan jumlah 36 siswa, dan kelas 4 dan 5 sejumlah 37 siswa. Wawancara, wawancara yang digunakan adalan wawancara secara terstruktur, dengan mencari informasi pada (kepala sekolah, guru kelas, dan pelatih tahfidz al-qur'an) dan studi dokumentasi. Tenik analisis data menggunakan analisis data secara interaktif model, dengan teknik pengecekan keabsahan data menggunakan triangulasi. Hasil penelitiannya yaitu pelaksanaan kegiatan ekstrakurikuler tahfidz al qur' an yang diikuti oleh seluruh siswa kelas 3, 4, dan 5 dengan jumlah keseluruhan 73 siswa, yang nantinya akan dibagi kelompok sesuai dengan jadwal yang telah dibuat oleh sekolah. Kegiatan ekstrakurikuler sebagai wadah pembentukan karakter siswa kearah yang positif. Melalui kegiatan ekstrakurikuler tahfidz al qur'an siswa mampu mengembangkan dirinya, mengasah bakat yang terpendam pada dirinya, dan lebih mencintai al qur' an untuk dihafalkan dengan lantunan bacaan yang merdu untuk didengarkan, dan mampu menjadi pribadi yang memiliki karakter baik dan percaya diri. Hasil penelitian ini dapat digunakan sebagai wawasan kepada pihak sekolah untuk selalu memberikan motivasi pada peserta didiknya untuk aktif dalam mengikuti kegitan esktrakurikuler tahfidz al qur'an sehingga nantinya hasil dari kegiatan tersebut mampu mencetak kader muda dan lulusan terbaik dari sekolah SD Muhammadiyah 1 Trenggalek.
\end{abstract}

Kata kunci: Penguatan Pendidikan Karakter, Ekstrakurikuler, Tahfidz Al Qur'an.

\section{ANALYSIS OF STRENGTHENING CHARACTER EDUCATION STUDENTS THROUGH TAHFIDZ AL QUR'AN}




\title{
Rizka, Nugrananda, Analisis Penguatan Pendidikan Karakter... EXTRACURRICULAR ACTIVITIES IN STUDENTS OF SD MUHAMMADIYAH 1 TRENGGALEK
}

\begin{abstract}
The pupose of this study is to describe the implementation of tahfidz al qur'an extracurricular activities, to descibe the character formation of students through tahfidz al qur'an extracurricular activities, to describe the impact of tahfidz al qur'an extracurricular activities on strengthening student character education. This research method includes the type of descriptive qualitative research. Data collection techniques used in the form of observation, using frank observation or disguised, this observation, observation made on students participating in tahfidz al qur'an extracurricular activities namely class 3 with a total of 36 students, and grades 4 and 5 were 37 students, interviews, intreviews, by looking for information on (principals, class teachers, and coaches of tahfidz al qur'an) and documentation studies. The data analysis technique uses interactive data analysis models, with the technique of checking the validity of the data using triangulation. The results of his research were the implementation of tahfidz al qur'an extracurricular activities which were attended by all students in grades 3, 4, and 5 with a total of 73 students, which would later be divided into groups according to the schedule made bye the school. Extracurricular activities as a forum for the formation of positive character toward students. Through the extracurricular activities of tahfidz al qur'an students are able to develop themselves, sharpen hidden talent in themselves, and love the qur'an to be memotized with melodious recitations to be heard, and able to become individuals who have good character and confidence. The results of this study can be used as insight to the school to always motivate students to be active in following the tahfidz al qur'an extracurricular activities so that the results of these activities can produce the best young cadres and graduates from the Muhammadiyah 1 Elementary School in Trenggalek.
\end{abstract}

Keywords: Character Education Strengthening, Extracurricular, Tahfidz Al Qur'an.

\section{PENDAHULUAN}

Pendidikan bagi peserta didik merupakan suatu hal yang tidak lepas dari kehidupan yang dialami sehari-hari oleh peserta didik. Undang-undang Dasar Republik Indonesia No. 20 Tahun 2003 tentang sistem pendidikan nasioanal pada pasal 1 ayat 1 menyebutkan bahwa pendidikan adalah usaha sadar dan terencana untuk mewujudkan suasana belajar dan proses pembelajaran agar peserta didik secara aktif mampu mengembangkan potensi pada dirinya untuk memiliki kekuatan spiritual keagamaan, pengendalian diri, kepribadian, kecerdasan, akhlak mulia serta ketrampilan yang diperlukan untuk dirinya, masyarakat, bangsa dan negara. Menurut (Mulyasa 2013, hal. 1) pendidikan karakter merupakan upaya untuk membantu perkembangan jiwa anak-anak 
Rizka, Nugrananda, Analisis Penguatan Pendidikan Karakter...

baik lahir maupun batin, dari sifat kodratinya menuju ke arah peradaban yang manusiawi dan lebih baik. Berdasarkan Undang-undang Perlindungan Anak, Nomor 23 Tahun. 2002 mengatakan, bahwa: "Pembentukan karakter seorang anak merupakan salah satu wujud kepedulian terhadap kesejahteraan anak di masa depan. Semua komponen bangsa mulai dari orang tua, keluarga, masyarakat, dunia usaha, pemerintah, dan negara memiliki kewajiban dan tanggung jawab terhadap perlindungan dan kesejahteraan anak. Dalam pembentukan karakter dapat membentuk pola berpikir yang bisa mempengaruhi perilakunya, perilaku tersebut yang nantinya akan membawa dia pada ketenangan dan kebahagiaan.

Pembentukan karakter di sekolah dapat dilaksanakan melalui pendidikan karakter, dan karakter ini muncul dengan sendirinya pada setiap diri manusia, karakter harus mampu diproses secara bertahap semenjak anak usia dini. Pendidikan karakter mampu diimplementasikan dalam setiap mata pelajaran maupun dalam setiap kegiatan siswa yang dilaksanakan di masing-masing sekolah sesuai dengan program sekolah, Oleh karena itu karakter ini perlu dibangun supaya kuat dan kokoh, salah satunya melalui penguatan pendidikan karakter yang diterapkan melalui kegiatan ekstrakurikuler di SD tersebut.

Penguatan pendidikan karakter merupakan sebuah gerakan pendidikan yang diimplementasikan oleh satuan pendidikan guna memperkuat pembentukan karakter siswa. (PERPRES R.I No. 87 2017). Peserta didik di sekolah dasar (SD) mempunyai karakterk yang berbeda-beda sesuai dengan berbagai hal yang konkrit dan praktis, selain dalam pendidikan formal penguatan pendidikan karakter juga dapat dilaksanakan dalam kegiatan ekstrakurikuler. Penguatan pendidikan karakter (PPK) terdapat 5 nilai-nilai karakternya (Religius, Nasionalis, Integritas, Mandiri, Gotong Royong)

Kegiatan ekstrakurikuler sebagaimana diatur dalam Undang - undang Nomor 20 Tahun 2003, menyebutkan bahwa "Pendidikan Nasional berfungsi mengembangkan kemampuan dan membentuk watak serta peradaban bangsa yang bermartabat dalam rangka mencerdaskan kehidupan bangsa, bertujuan untuk berkembangnya potensi peserta didik agar menjadi manusia yang beriman kepada Tuhan Yang Maha Esa, berakhlak mulia, sehat, berilmu, cakap, kreatif, mandiri, dan menjadi warga negara yang demokratis serta bertanggung jawab, oleh karena itulah ekstrakurikuler menjadi tambahan bagi peserta didik yang mampu memberikan sikap positif di masing-masing sekolah. 
Rizka, Nugrananda, Analisis Penguatan Pendidikan Karakter...

Kegiatan esktrakurikuler yang terdapat di SD Muhammadiyah 1 Trenggalek peneliti menganalisis pada kegiatan ekstrakurikuler tahfidz Al Qur'an. Ekstrakurikuler tahfidz Al Qur'an merupakan salah satu pembelajaran menghafal pada rangkaian ayat yang terdapat didalam Al Qur'an. Tahfidz Al Qur'an melatih ingatan dalam menghafal al-qur'an atau proses membaca secara berulang-ulang dengan memerlukan konsentrasi penuh dan fokus, karena menghafal itu tidak lah mudah, namun jika sering diulang maka hafalanpun akan mudah dibaca. kegiatan ektrakurikuler mampu memberikan efek terhadap kepribadian seseorang, kepribadian ini terbentuk tidak pernah lepas dari perananan yang terdapat di masyarakat dimana individu dibesarkan.

Sekolah mempunyai peranan penting dalam pembentukan kepribadian anak yang mampu dikemas melalui kegiatan belajar mengajar di kelas dan juga belajar di luar jam kurikulum seperti kegiatan ektrakurikuler, ini dimaksudkan agar anak mampu menyalurkan bakat, minat, karya, serta kreativitas anak sesuai dengan bidang yang mereka sukai dan ini perlu diperhatikan oleh seluruh pendidik agar peserta didiknya tidak merasa bosan karena hanya mengikuti kelas formal.

Penelitian yang dilakukan peneliti di SD Muhammadiyah 1 Trenggalek ini didukung oleh penelitian yang telah dilakukan (Dahliyana, 2017) dengan judul "Penguatan Pendidikan Karakter Melalui Kegiatan Ekstrakurikuler di SMA Negeri 3 Bandung" penelitian tersebut menghasilkan suatu kesimpulan bahwa, hubungan kegiatan ekstrakurikuler dengan pendidikan karakter yaitu sebagai tanggung jawab antara pengetahuan yang diperoleh di kelas dengan sikap dan keterampilan yang harus dikembangkan agar dapat dimiliki siswa berupa nilai-nilai budi pekerti luhur yang telah menjadi budaya dalam kehidupan sosial sekolah.

Berdasarkan uraian di atas membuat peneliti ingin mengetahui bahwa kegiatan ekstrakurikuler tahfidz mampu memberikan penguatan pendidikan karakter pada peserta didik. Sehingga peneliti menuangkannya kedalam penelitian yang bertujuan untuk menganalisis penguatan pendidikan karakter peserta didik melalui kegiatan ekstrakuriuler tahfidz Al Qur'an pada siswa SD Muhammadiyah 1 Trenggalek tahun pelajaran 2018/2019".

\section{METODE}




\section{Rizka, Nugrananda, Analisis Penguatan Pendidikan Karakter...}

Jenis penelitian ini merupakan jenis penelitian kualitatif. Menurut Sugiyono (2017, hal 3), menyatakan metode penelitian kualitatif digunakan untuk mendapatkan data yang mendalam, suatu data yang mengandung makna. Makna adalah data yang sebenarnya, data yang pasti yang merupakan suatu nilai di balik data yang tampak. Pendekatan yang digunakan dalam penelitian ini adalah pendekatan deskriptif kualitatif, karena data yang dikumpulkan berupa kata-kata, gambar-gambar dan bukan angka.

Penelitian ini diharapkan mampu mengungkapkan berbagai informasi secara deskripsi dan analisis untuk menghasilkan data penuh dengan makna yang jelas, tidak menolak informasi kuantitatif dalam bentuk angka maupun jumlah jika dalam data yang akan peneliti teliti muncul data angka tersebut. Mengenal dan memahami karakteristik yang terdapat dalam jenis penelitian kualitatif akan mempermudahkan peneliti dalam mengambil data, mengumpulkan data, menganalisis data maupun mengembangkan hasil dari laporan hasil penelitian. Laporan penelitian ini berisi tentang data-data yang diambil melalui kutipan-kutipan data yang memberikan gambaran dan informasi tentang penguatan pendidikan karakter melalui kegiatan ekstrakurikuler tahfidz al qur'an siswa SD Muhammadiyah 1 Trenggalek. Tahap penelitian kualitatif dengan salah satu ciri pokoknya peneliti menjadi sebagai alat penelitian. Penelitian ini mempersoalkan pada tahap-tahap penelitian yang nantinya memberikan gambaran tentang keseluruhan perencanaan, pelaksanaan pengumpulan data, analisis dan penafsiran data, sampai penulisan laporan.

Prosedur penelitian. Menurut Moleong (2012, hal. 126) mempelajari penelitian kualitatif tidak terlepas dari usaha mengenal tahap-tahap penelitian. Moleong (2012, hal. 127-148) menyatakan, bahwa tahap penelitian secara umum untuk penelitian kualitatif terdiri atas tahap pralapangan, tahap pelaksanaan lapangan, dan tahap analisis data. Subyek penelitian yang utama adalah pada siswa SD Muhammadiyah 1 Trenggalek, sedangkan subyek pendukungnya adalah Bapak Kepala Sekolah, Guru Kelas 3, Guru Kelas 4, dan Kelas 5, dan Pelatih Tahfidz Al qur'an. Waktu penelitian dimulai pada bulan Maret 2019 sampai dengan bulan Mei 2019. Lokasi penelitian SD Muhammadiyah 1 Trenggalek.

Instrumen penelitian. Menurut Sugiyono (2017, hal. 305) penelitian kualitatif, yang menjadi instrumen atau alat penelitian adalah peneliti itu sendiri. instrumen dalam penelitian kualitatif berupa. Pedoman observasi yang digunakan peneliti untuk 
Rizka, Nugrananda, Analisis Penguatan Pendidikan Karakter...

memperoleh data yang terdapat di lapangan yang diperoleh dari pengamatan peneliti sendiri terhadap para siswa ketika sedang melaksanakan kegaitan ekstrakurikuler tahfidz al qur'an. Pedoman wawancara digunakan peneliti untuk memperoleh data secara detail yang dilakukan peneliti secara langsung dari informan di lapangan. Dokumentasi digunakan peneliti sebagai sebagai alat bantu dalam mendukung informasi yang diperoleh peneliti terkait dengan penelitian penguatan pendidikan karakter peserta didik melalui kegiatan ekstrakurikuler tahfidz al qur'an.

Teknik pengumpulan data. Menurut Sugiyono (2017, hal. 308-332) merupakan langkah yang paling utama dalam penelitian, karena tujuan utama dari penelitian adalah mendapatkan data. Teknik pengumpulan data dalam penelitian ini menggunakan observasi, wawancara, dan dokumentasi. Observasi yang dilakukan oleh peneliti menggunakan observasi terus terang atau tersamar, tujuannya untuk menganalisis kondisi yang akan diteliti sebagai tahap awal di SD Muhammadiyah 1 Trenggalek tersebut terhadap analisis penguatan pendidikan karakter peserta didik melalui kegiatan ektrakurikuler yang mengacu pada kegiatan ekstrakurikuler tahfidz al qur'an pada siswa SD Muhammadiyah 1 Trenggalek. Wawancara yang dilakukan oleh peneliti menggunakan wawancara terstruktur, tujuannya mengetahui dengan pasti tentang informasi yang akan diperoleh, wawancara dilakukan secara mendetail untuk memperoleh data yang dikumpulkan sesuai dengan yang dilaksanakan peneliti tentang analisis penguatan pendidikan karakter peserta didik melalui kegiatan ekstrakurikuler yang mengacu pada ekstrakurikuler tahfidz al-qur'an siswa SD Muhammadiyah 1 Trenggalek. Studi Dokumentasi dalam penelitian kualitatif merupakan pelengkap dari penggunaan metode observasi dan wawancara. Dokumen yang dipilih yaitu dokumen yang sesuai dengan tujuan dan fokus penelitian tentang analisis penguatan pendidikan karakter peserta didik melalui kegiatan ekstrakurikuler yang mengacu pada ekstrakurikuler tahfidz al qur'an siswa.

Teknik analisis data. Menurut Sugiyono (2017, hal. 335) proses mencari dan menyusun secara sistematis data yang diperoleh dari hasil wawancara, observasi, dan dokumentasi, dengan cara mengorganisasikan data ke dalam kategori, menjabarkan ke dalam unit-unit, melakukan sintesa, menyusun ke dalam pola, memilih mana yang penting dan yang akan dipelajari, dan membuat kesimpulan sehingga mudah difahami 
Rizka, Nugrananda, Analisis Penguatan Pendidikan Karakter...

oleh diri sendiri maupun orang lain. Analisis data dalam penelitian kualitatif dilakukan pada saat pengumpulan data berlangsung, dan pengumpulan data dalam periode tertentu.

Menurut Miles and Huberman (1984) seperti dikutip dalam Sugiyono (2017, hal. 337) mengemukakan bahwa aktivitas dalam analisis data kualitatif dilakukan secara interaktif dan berlangsung secara terus menerus sampai tuntas, sehingga datanya sudah jenuh. Aktivitas yang terdapat dalam analisis data yaitu, data collection (pengumpulan data), data reduction (reduksi data), data display (penyajian data), data conclusion drawing/verification (kesimpulan).

Pengecekan keabsahan data kualitatif ini peneliti menggunakan teknik pengumpulan data triangulasi, menurut Sugiyono (2017, hal. 330) teknik pengumpulan data triangulasi bersifat menggabungkan dari berbagai teknik pengumpulan data dan sumber data yang telah ada. Pengecekan keabsahan data yang peneliti gunakan adalah melalui triangulasi dengan (sumber) berarti membandingkan dan mengecek balik derajat kepercayaan suatu informasi yang diperoleh melalui waktu dan alat yang berbeda.

\section{HASIL}

Pada bagian ini memaparkan data hasil penelitian yang meliputi hasil observasi, hasil hasil wawancara.

Tabel 4.1

Hasil Observasi (PPK) Pada Siswa Kelas (III, IV dan V) Tahfidz Al Qur'an

\begin{tabular}{|c|c|c|c|c|c|c|c|}
\hline \multirow[b]{2}{*}{ No. } & \multirow[b]{2}{*}{$\begin{array}{l}\text { Aspek yang } \\
\text { diamati }\end{array}$} & \multicolumn{5}{|c|}{ Nilai PPK } & \multirow[b]{2}{*}{ Keterangan } \\
\hline & & $\begin{array}{l}\text { Reli- } \\
\text { gius }\end{array}$ & $\begin{array}{c}\text { Nasi- } \\
\text { onali } \\
\text { s }\end{array}$ & $\begin{array}{l}\text { Inte- } \\
\text { gritas }\end{array}$ & $\begin{array}{c}\text { Man- } \\
\text { diri }\end{array}$ & $\begin{array}{l}\text { Got- } \\
\text { ong } \\
\text { Roy- } \\
\text { ong }\end{array}$ & \\
\hline & \multicolumn{6}{|c|}{ Bentuk Penguatan Pendidikan Karakter } & \\
\hline 1. & $\begin{array}{l}\text { a. Penguatan } \\
\text { pendidikan } \\
\text { karakter kegiatan } \\
\text { ekstrakurikuler. }\end{array}$ & $\sqrt{ }$ & $\sqrt{ }$ & $\sqrt{ }$ & $\sqrt{ }$ & $\sqrt{ }$ & $\begin{array}{l}\text { Penguatan pendidikan karakter (PPK) } \\
\text { tidak asing lagi dikenal oleh siswa, } \\
\text { (PPK) disetiap pelaksanaan kegiatan di } \\
\text { SD Muhammadiyah } 1 \text { Trenggalek. }\end{array}$ \\
\hline & $\begin{array}{l}\text { b. Pelaksanaan } \\
\text { kegiatan } \\
\text { ekstrakurikuler } \\
\text { tahfidz al qur'an. }\end{array}$ & $\sqrt{ }$ & - & - & - & - & $\begin{array}{l}\text { - Siswa kelas III dalam mengikuti } \\
\text { pelaksanaan ekstrakurikuler } \\
\text { tahfidz dengan baik, meskipun ada } \\
\text { beberapa siswa masih sulit } \\
\text { dikendalikan. } \\
\text { - Siswa kelas IV dan V mampu } \\
\text { mengikuti ekstrakurikuler dengan } \\
\text { baik karena jenjang mereka } \\
\text { berada pada kelas tinggi jadi }\end{array}$ \\
\hline
\end{tabular}


Rizka, Nugrananda, Analisis Penguatan Pendidikan Karakter...

\begin{tabular}{|c|c|c|c|c|c|c|c|}
\hline & & & & & & & $\begin{array}{l}\text { sudah mampu dikendalikan } \\
\text { pelatih dengan baik. }\end{array}$ \\
\hline & $\begin{array}{l}\text { c. Penerapan } \\
\text { karakter pada } \\
\text { peserta didik } \\
\text { melalui kegiatan } \\
\text { ekstrakurikuler } \\
\text { tahfidz al qur'an }\end{array}$ & $\sqrt{ }$ & $\sqrt{ }$ & - & - & - & $\begin{array}{l}\text { Pada siswa kelas III secara perlahan } \\
\text { dilatih dengan baik dan lancar, } \\
\text { meskipun masih ada beberapa yang } \\
\text { sulit dalam penanganannya. } \\
\text { Memunculkan pula karakter pada } \\
\text { diri peserta didik. } \\
\text { - Pada siswa kelas IV dan V mampu } \\
\text { bertanggung, disiplin dalam } \\
\text { mengikuti kegiatan tersebut dengan } \\
\text { baik dan sikap dewasa. }\end{array}$ \\
\hline & \multicolumn{6}{|c|}{$\begin{array}{c}\text { Bentuk pelaksanaan (PPK) yang dilaksanakan melalui } \\
\text { kegiatan ekstrakurikuler }\end{array}$} & \\
\hline \multirow[t]{2}{*}{2.} & $\begin{array}{l}\text { a. Siswa } \\
\text { melaksanakan } \\
\text { do'a sebelum } \\
\text { melaksanakan } \\
\text { kegiatan tahfidz } \\
\text { dan selesai } \\
\text { melaksanakan } \\
\text { kegiatan tahfidz } \\
\text { tersebut. }\end{array}$ & $\sqrt{ }$ & - & - & - & - & $\begin{array}{l}\text { - Siswa kelas III masih ada yang } \\
\text { bermain sendiri, dan saat } \\
\text { melaksakan do'a bersama masih } \\
\text { ada yang belum lancar. Tetapi tidak } \\
\text { mengurangi ke khusukan berdo'a } \\
\text { dari pada siswa yang lainnya, } \\
\text { karena ada pelatih yang } \\
\text { mendampingi } \\
\text { - Siswa kelas IV dan V khusuk } \\
\text { dalam melaksanakan do'a sebelum } \\
\text { memulai kegiatan ekstrakurikuler } \\
\text { tahfidz tersebut. } \\
\end{array}$ \\
\hline & $\begin{array}{l}\text { b. Siswa memulai } \\
\text { hafalan tahfidz al- } \\
\text { qur'an dengan } \\
\text { bantuan pelatih. }\end{array}$ & $\sqrt{ }$ & - & $\sqrt{ }$ & $\sqrt{ }$ & - & $\begin{array}{l}\text { Seluruh siwa kelas (III, IV, dan V) } \\
\text { yang telah mengikuti kegiatan } \\
\text { ekstrakurikuler tahfidz al-qur'an sesuai } \\
\text { dengan jadwal yang sudah di bentuk } \\
\text { oleh sekolah, dilaksanakan dengan } \\
\text { baik. Pelatih selalu memberikan } \\
\text { motivasi dan semangat untuk para } \\
\text { siswa untuk menyelesaikan hafalan } \\
\text { tersebut. }\end{array}$ \\
\hline & $\begin{array}{l}\text { c. Siswa bersama } \\
\text { teman saling bantu } \\
\text { membantu dalam } \\
\text { menghafalkan } \\
\text { ayat al qur'an. }\end{array}$ & $\sqrt{ }$ & - & - & - & $\sqrt{ }$ & $\begin{array}{l}\text { Siswa kelas (III, IV, dan V) dilatih } \\
\text { untuk saling membantu satu sama lain. }\end{array}$ \\
\hline & $\begin{array}{l}\text { d. Evaluasi pelatih } \\
\text { pada pembelajaran } \\
\text { tahfidz al qur'an } \\
\text { terhadap peserta } \\
\text { didik. }\end{array}$ & - & $\sqrt{ }$ & $\sqrt{ }$ & $\sqrt{ }$ & - & $\begin{array}{l}\text { Siswa kelas (III, IV dan V) mampu } \\
\text { bersikap baik terhadap teman } \\
\text { sebayanya, dan juga orang yang lebih } \\
\text { tua dari mereka. }\end{array}$ \\
\hline \multirow[b]{2}{*}{3.} & \multicolumn{6}{|c|}{$\begin{array}{l}\text { Upaya pelatih dalam mengatasi kendala yang dihadapi } \\
\text { oleh para siswanya dalam menghafal. }\end{array}$} & \\
\hline & $\begin{array}{ll}\text { a. } & \text { Siswa diajak } \\
\text { bermain } & \\
\text { sambil belajar } \\
\text { menghafal } \\
\text { oleh pelatih. }\end{array}$ & $\sqrt{ }$ & - & - & - & - & $\begin{array}{l}\text { Pembelajaran yang menggunakan } \\
\text { strategi agar siswa tidak jenuh dan } \\
\text { bertujuan untuk menguatkan hafalan } \\
\text { siswa. Siswa kelas (III, IV dan V) } \\
\text { sesuai jadwal dari sekolah. }\end{array}$ \\
\hline
\end{tabular}


Rizka, Nugrananda, Analisis Penguatan Pendidikan Karakter...

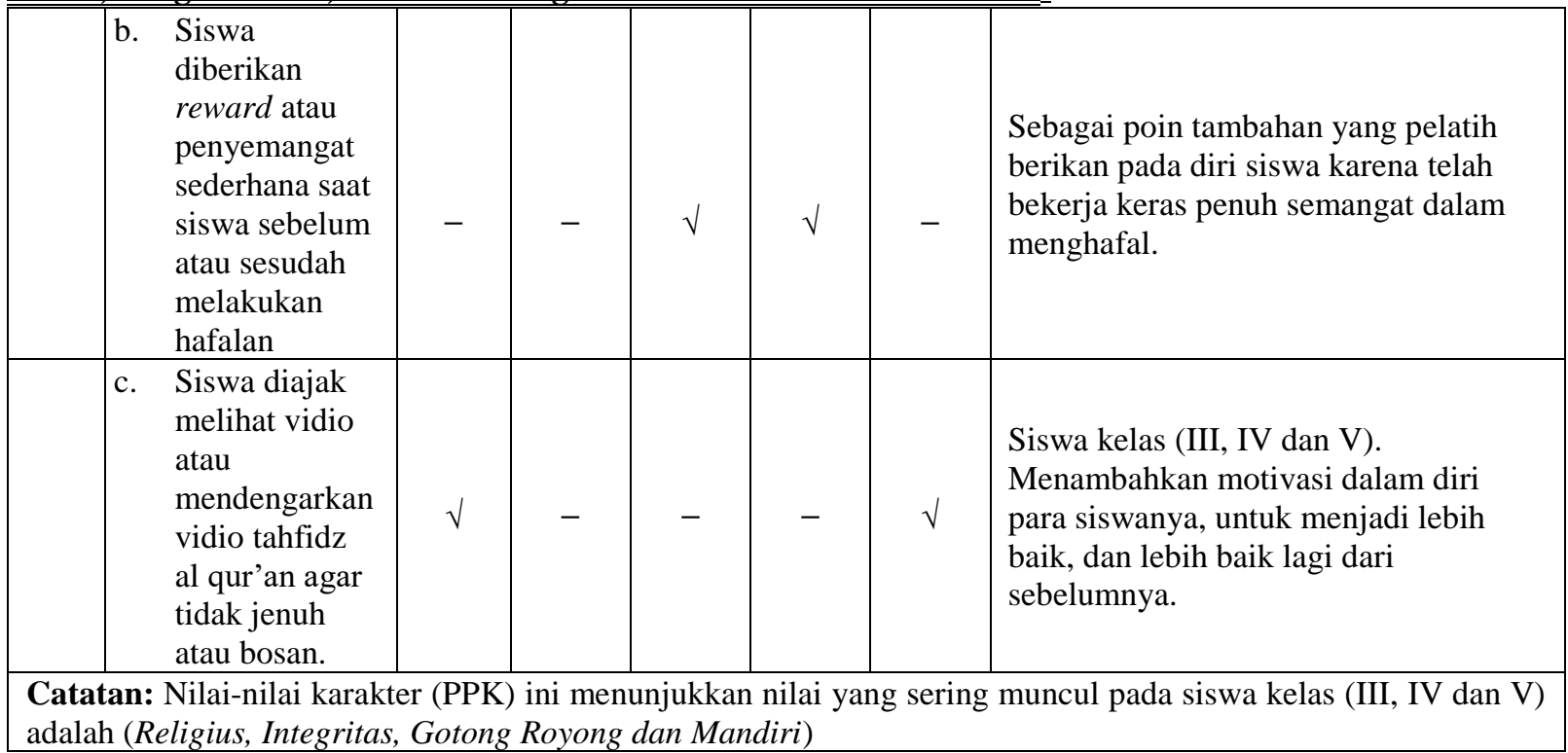

Tabel 4.2

Hasil Wawancara Pelatih Tahfidz Al Qur'an

\begin{tabular}{|c|c|c|}
\hline No. & Pertanyaan & Jawaban \\
\hline 1. & $\begin{array}{l}\text { Bagaimana menurut bapak/ibu tentang penguatan } \\
\text { pendidikan karakter (PPK) pada peserta didik di } \\
\text { sekolah dasar? }\end{array}$ & $\begin{array}{l}\text { Penguatan pendidikan karakter penting untuk diterapkan } \\
\text { disatuan pendidikan seperti yang dicanangkan oleh } \\
\text { Kemendikbud (2017). Penguatan pendidikan karakter di } \\
\text { sekolah dasar sangat baik, karena dengan penguatan } \\
\text { pendidikan karakter yang sudah diterapkan di sekolah } \\
\text { dasar. }\end{array}$ \\
\hline 2. & $\begin{array}{l}\text { Pentingkah penguatan pendidikan karakter } \\
\text { diberikan kepada peserta didik? }\end{array}$ & $\begin{array}{l}\text { Sangat penting, karena penguatan pendidikan karakter } \\
\text { inilah yang menjadi dasar penting dalam membentuk } \\
\text { nilai-nilai karakter pada diri seluruh peserta didik di } \\
\text { sekolah dasar, salah satuny yang sudah di terapkan di SD } \\
\text { Muhammadiyah } 1 \text { Trenggalek. }\end{array}$ \\
\hline 3. & $\begin{array}{l}\text { Bagaimanakah proses pelaksanaan pembelajaran } \\
\text { tahfidz al-qur'an di kelas ekstrakurikuler yang } \\
\text { bapak/ibu ajarkan? }\end{array}$ & $\begin{array}{l}\text { Pelaksanaan tahfidz di SD Muhammdiyah } 1 \text { Trenggalek } \\
\text { telah disesuaikan dengan yang terdapat pada program } \\
\text { unggulan sekolah "tuntas pembelajaran al-qur'an (TPA)" } \\
\text { untuk mencapai target yang diharapkan oleh sekolah. } \\
\text { Pelaksanaan tahfidz dalam menghafal atau melantunkan } \\
\text { ayat dalam al-qur'an menggunakan metode tajdid (metode } \\
\text { yang cara membacanya dengan menggunakan tepukan). }\end{array}$ \\
\hline 4. & $\begin{array}{l}\text { Bagaimana pendapat bapak/ibu tentang } \\
\text { ekstrakurikuler tahfidz al-qur'an yang dilaksanakan } \\
\text { di SD Muhammadiyah } 1 \text { Trenggalek? }\end{array}$ & $\begin{array}{l}\text { Sangat baik, karena dengan adanya kegiatan } \\
\text { ekstrakurikuler tahfidz tersebut, para peserta didik mampu } \\
\text { terbentuk secara perlahan dengan baik, misalkan saja } \\
\text { sikap dia dengan para guru lebih sopan, cara bicarapun } \\
\text { tertata dengan baik, bahkan dengan para teman mampu } \\
\text { berinteraksi dengan baik. }\end{array}$ \\
\hline 5. & $\begin{array}{l}\text { Dalam menghafalkan al-qur'an adakah strategi } \\
\text { yang bapak/ibu sebagai pelatih lakukan untuk } \\
\text { peserta didik agar mudah dalam mengingat } \\
\text { hafalannya? }\end{array}$ & $\begin{array}{l}\text { Pelatih tidak terlalu menggunakan strategi, hanya saja } \\
\text { yang pelatih lakukan adalah dengan pendekatan yang } \\
\text { mampu berdampak pada diri anak, dan dalam } \\
\text { pembelajaran ekstrakurikuler tahfidz al-qur'an ini pelatih } \\
\text { menyelingkannya dengan game atau permainan, ini }\end{array}$ \\
\hline
\end{tabular}


Rizka, Nugrananda, Analisis Penguatan Pendidikan Karakter...

\begin{tabular}{|c|c|c|}
\hline & & $\begin{array}{l}\text { berupaya agar para peserta didiknya tidak jenuh dalam } \\
\text { menghafal, yaitu permainan (teks acak ayat). }\end{array}$ \\
\hline 6. & $\begin{array}{l}\text { Adakah kendala yang dihadapi pelatih dalam } \\
\text { melaksanakan kegiatan ekstrakurikuler tahfidz al- } \\
\text { qur'an? }\end{array}$ & $\begin{array}{l}\text { Selama ini belum ada kendala, karena selain dari pelatih } \\
\text { sediri yang membantu hafalan para peserta didik, disini } \\
\text { juga dibantu oleh para guru kelas dengan membantu } \\
\text { menyimak hafalan peserta didiknya masing-masing di SD } \\
\text { Muhammadiyah } 1 \text { Trenggalek tersebut. Jadi semua } \\
\text { mampu berjalan dengan baik. }\end{array}$ \\
\hline 7. & $\begin{array}{l}\text { Apa harapan bapak/ibu pelatih kepada para peserta } \\
\text { didik terhadap penguatan pendidikan karakter } \\
\text { (PPK) dirinya melalui kegiatan ekstrakurikuler } \\
\text { tahfidz al-qur'an yang bapak/ibu bina? }\end{array}$ & $\begin{array}{l}\text { Harapannya siswa nantinya bisa lebih mandiri, } \\
\text { bertanggung jawab pada diri mereka sendiri-sendiri, } \\
\text { mempunyai semangat dalam menghafal dikelas maupun } \\
\text { diluar kelas, dan juga nantinya bisa mengajak teman } \\
\text { dalam menghafal dan memotivasi teman yang lain. }\end{array}$ \\
\hline 8. & $\begin{array}{l}\text { Bagaimana pendapat bapak/ibu pelatih tahfidz al- } \\
\text { qur'an tentang pentingnya nilai-nilai karakter yang } \\
\text { terkandung pada (PPK) di sekolah? }\end{array}$ & $\begin{array}{l}\text { Sangat penting, karena nilai-nilai karakter inilah yang } \\
\text { akan mampu dihasilkan dengan baik atau tidaknya pada } \\
\text { diri anak dalam penguatan pendidikan karakternya. Dari } \\
\text { cara pembiasaan dan melalui kegiatan ekstrakurikuler } \\
\text { tahfidz ini pelatih mampu mengetahui nilai karakter yang } \\
\text { sering muncul pada diri siswa saat mengikuti kegiatan } \\
\text { ekstrakurikuler tahfidz tersebut yaitu pada nilai karakter } \\
\text { (Religius, Integritas, Mandiri, dan Gotong Royong), nilai } \\
\text { yang belum muncul bukan karena tidak muncul, hanya } \\
\text { saja nilai yang sering terlihat pada diri siswa adalah nilai } \\
\text { karakter tersebut. }\end{array}$ \\
\hline 9. & $\begin{array}{l}\text { Motivasi seperti apakah yang bapak/ibu pelatih } \\
\text { berikan pada peserta didik agar tidak menyerah } \\
\text { dalam menghafalkan al-qur'an? }\end{array}$ & $\begin{array}{l}\text { Motivasi yang diberikan adalah motivasi-motivasi } \\
\text { kedepannya untuk peserta didik dikemudian hari, }\end{array}$ \\
\hline 10. & $\begin{array}{l}\text { Apakah yang membuat bapak/ibu pelatih bangga } \\
\text { terhadap kegiatan ekstrakurikuler tahfidz al-qur'an } \\
\text { yang terdapat di SD Muhammadiyah } 1 \text { Trenggalek? }\end{array}$ & $\begin{array}{l}\text { Bangga, karena bisa memberikan manfaat pada sekolah } \\
\text { dan orang yang ada disekitarnya, membawa nama baik } \\
\text { orang tua dan sekolah. Dan secara tidak langsung anak } \\
\text { lebih suka dan senang. }\end{array}$ \\
\hline
\end{tabular}

\section{PEMBAHASAN}

Pada bab ini, disajikan uraian pembahasan sesuai dengan hasil penelitian yang diperoleh dari lapangan melalui wawancara terstruktur, observasi terus terang atau tersamar, dan dokumentasi. Pembahasan ini akan memaparkan hasil penelitian tentang "Analisis Penguatan Pendidikan Karakter Peserta Didik Melalui Kegiatan Ekstrakurikuler Tahfidz Al Qur'an Pada Siswa SD Muhammadiyah 1 Trenggalek" dan menganalisisnya dengan teori yang ada.

Berdasarkan hasil observasi dilakukan pada siswa kelas III, IV, dan V sejumlah 73 siswa yang dibagi menjadi dua gelombang sesuai dengan jadwal kegiatan ekstrakurikuler tahfidz tersebut. Sesuai dengan paparan observasi diatas melalui aspek yang diamati ditemukan bahwa nilai-nilai karakter yang terdapat dalam PPK ini memunculkan nilai-nilai karakter yang sering muncul diantaranya (religius, integritas, mandiri, dan gotong royong). Sedangkan nilai yang belum muncul, bukan karena tidak 
Rizka, Nugrananda, Analisis Penguatan Pendidikan Karakter...

muncul, tetapi yang terlihat menonjol saat dilakukan observasi oleh peneliti adalah nilai karakter tersebut. Nilai-nilai karakter dalam penguatan pendidikan karakter yang sering muncul pada diri siswa kelas III, IV, dan V ini akan diperkuat lagi dengan hasil wawancara pelatih tahfidz al qur'an.

Berdasarkan wawancara yang dilakukan peneliti dengan pelatih tahfidz al qur'an menghasilkan bahwa Nilai-nilai karakter yang terdapat pada penguatan pendidikan karakter sangat penting untuk peserta didik disatuan pendidikan, karena nilai-nilai karakter inilah yang akan mampu dihasilkan dengan baik atau tidaknya pada diri anak dalam penguatan pendidikan karakternya selain itu, nilai-nilai karakter yang nanti muncul pada diri peserta didik adalah nilai-nilai yang diharapkan mampu membawa dampak positif bagi diri peserta didik sendiri dan orang disekitarnya.

Cara membiasakan peserta didik dengan hal yang positif untuk membentuk karakter baik pada diri siswa, peneliti amati melalui pembiasan berikut. Selesai siswa melaksanakan sholat dhuha berjama'ah, siswa dibiasakan untuk melakukan pengulangan hafalan dengan didampingi oleh pelatih dan bisa juga dengan guru kelas masing-masing. Hal ini untuk mengecek seberapa jauh hafalan yang telah dilakukan oleh para siswa tersebut, Pembiasaan lainnya dalam menghafal tahfidz Al Qur'an ini bisa dilaksanakan siswa di dalam kelas, maupun di luar kelas dan dilaksanakan disela-sela kekosongan mereka. Dari cara pembiasaan dan melalui kegiatan ekstrakurikuler tahfidz ini, pelatih mampu mengetahui nilai karakter yang sering muncul pada diri siswa saat mengikuti kegiatan ekstrakurikuler tahfidz tersebut yaitu pada nilai karakter (Religius, Integritas, Mandiri, dan Gotong Royong).

Berdasarkan paparan diatas maka peneliti menemukan bahwa penguatan pendidikan karakter pada peserta didik melalui kegiatan ekstrakurikuler, salah satunya melalui kegiatan ekstrakurikuler tahfidz al qur'an ini dapat berpengaruh terhadap pembentukan karakter peserta didik. Karakter peserta didik mampu dibentuk secara berproses dan baik melalui kegiatan yang positif, seperti yang terdapat dan sudah dilaksanakan di SD Muhammadiyah 1 Trenggalek, bahwa program sekolah di SD tersebut mampu diterapkan dan dilaksanakan dalam semua bidang termasuk pada kegiatan ektrakurikuler, dan mampu menghasilkan sesuai yang diharapkan oleh sekolah. 
Rizka, Nugrananda, Analisis Penguatan Pendidikan Karakter...

\section{SIMPULAN}

Berdasarkan hasil penelitian pembahasan yang telah dilaksanakan mengenai analisis penguatan pendidikan karakter peserta didik melalui kegiatan ekstrakurikuler tahfidz al qur'an pada SD Muhammadiyah 1 Trenggalek dapat disimpulkan sebagai berikut:

1. Pelaksanaan kegiatan ekstrakurikuler tahfidz Al Qur'an SD Muhammadiyah 1 Trenggalek dilaksanakan sesuai dengan program unggulan tuntas pembelajaran alqur'an (TPA) dengan baik, sesuai prosedur dan mendapatkan hasil yang positif dalam pelaksanaan tersebut. Sehingga para peserta didik mampu mengikuti dengan tertib dan baik. Pelaksanaan kegiatan ekstrakurikuler tahfidz Al Qur'an mampu menambah pengetahuan pada peneliti, bahwa pembelajaran tahfidz Al-Qur'an ini ternyata menyenangkan, membuat hati lebih tenang, nyaman dan damai, karena lantunan ayat suci dalam Al Qur'an yang mampu memberikan dampak positif pada kepribadian siswa maupun orang di sekitarnya atau orang yang mendengarkannya.

2. Pembentukan karakter peserta didik melalui kegiatan ekstrakurikuler tahfidz Al Qur'an SD Muhammadiyah 1 Trenggalek perlu dikuatkan dengan adanya penguatan pendidikan karakter. Penguatan pendidikan karakter (PPK) melalui kegiatan ekstrakurikuler tahfidz Al Qur'an, diharapkan mampu membentuk karakter siswa sehingga bisa mandiri, bertanggung jawab pada diri sendiri, mempunyai semangat dalam menghafal di kelas maupun di luar kelas, dan bisa mengajak teman dalam menghafal dan memotivasi teman yang lain dalam menghafal. Penguatan pendidikan karakter terdapat nilai-nilai (PPK) di dalamnya. Nilai karakter ini sangat penting untuk dibentuk pada diri masing-masing peserta didik. Nilai yang sering muncul pada diri peserta didik dalam pembentukan karakter melalui kegiatan ekstrakurikuler tahfidz Al Qur'an ini adalah nilai (religius, integritas, mandiri, dan gotong royong). Nilai yang belum muncul bukan karena tidak muncul, hanya saja yang terlihat menonjol saat dilakukan observasi adalah nilai-nilai karakter tersebut.

3. Dampak kegiatan ekstrakurikuler tahfidz Al Qur'an terhadap penguatan pendidikan karakter (PPK) siswa, memberikan dampak positif terhadap kepribadian karakter siswa. Para siswa mampu bersikap baik di dalam kelas dengan teman sebayanya, sopan dan santun dengan para bapak/ibu guru, bertanggung jawab dengan keputusan yang diambil, dan mampu bertanggung jawab dengan tugas yang diberikan oleh 
Rizka, Nugrananda, Analisis Penguatan Pendidikan Karakter...

bapak/ibu guru mereka. Dampak kegiatan ekstrakurikuler tahfidz Al Qur'an pada siswa SD Muhammadiyah 1 Trenggalek adalah mampu membentuk karakter secara bertahap pada diri siswa. Orang tua yang menyekolahkan siswanya di sekolah tersebut tidak merasakan kekecewaan, tetapi merasakan kebanggaan karena sekolah mampu mendidik karakter siswa sesuai dengan yang diharapkan. Pihak sekolah pun bertujuan untuk mencetak kader, generasi penerus estafet bangsa yang berkarakter, sesuai dengan yang dicanangkan oleh Kemendikbud (2017) tentang "Penguatan Pendidikan Karakter".

\section{UCAPAN TERIMA KASIH}

Tanpa mengurangi rasa syukur kepada Allah SWT, penelitian ini saya persembahkan kepada:

1. Untuk keluargaku, Bapak, Ibu, Adik, terima kasih atas segala kasih sayang, doa sehingga dilancarkan dalam segala hal.

2. Dosen pembimbing Bapak Nugrananda Janattaka, M.Pd, terima kasih atas segala bantuannya, nasehat, sehingga dilancarkan dalam segala hal.

3. Untuk teman-temanku tercinta, terima kasih atas dukungan, do'a, motivasi, dan semangat yang telah kalian berikan.

\section{DAFTAR RUJUKAN}

Asep Dahliyana. 2017. Penguatan Pendidikan Karakter Melalui Kegiatan Ekstrakurikuler Di Sekolah. Vol 15, No. 1

Budi Santoso, 2018. Penguatan Pendidikan Karakter Melalui Kegiatan Ekstrakurikuler Di Sekolah. Vol 15, No. 1

Lexy J. Moleong. 2012. Metodelogi Penelitian Kualitatif. Bandung. PT Remaja Rosdakarya.

Mulyasa. 2013. Manajemen Pendidikan Karakter. Jakarta. PT Bumi Aksara.

Sugiyono. 2017. Metode Penelitian Pendidikan. Bandung. Penerbit Alfabeta.

Tim Penyusun Kementerian Pendidikan dan Kebudayaan Republik Indonesia. 2017.

Konsep dan Pedoman Penguatan Pendidikan Karakter Tingkat Sekolah Dasar dan Sekolah Menengah Pertama. Jl. Jenderal Sudirman. Jakarta. 